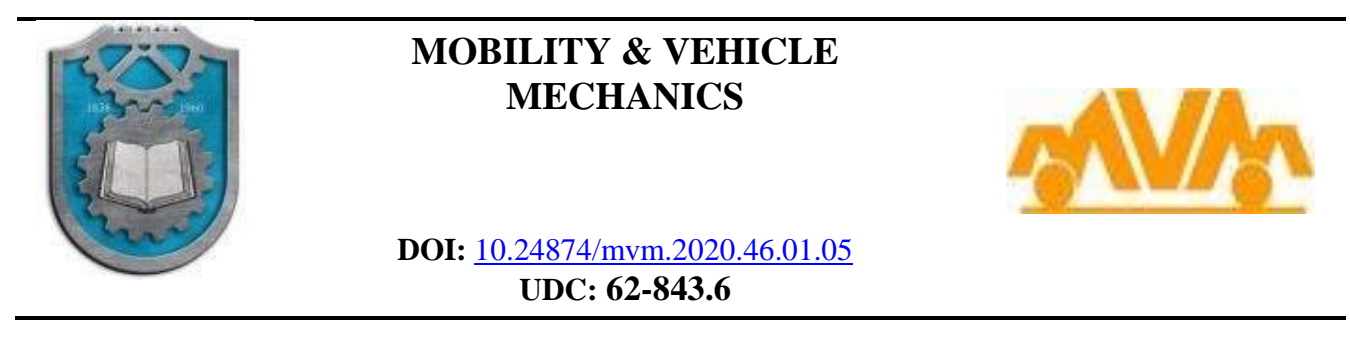

\title{
INVESTIGATION OF DIESEL ENGINE OPERATED WITH DIESEL FUEL-BUTANOL BLENDS AND CETANE IMPROVER
}

Hristo Stanchev ${ }^{I^{*}}$, Krasimir Markov ${ }^{2}$

Received in October 2018 Accepted in January 2020

\section{RESEARCH ARTICLE}

ABSTRACT: Experimental investigation of a common rail direct injection diesel engine is carried out, when working with diesel fuel in blends with $10 \%$ (B10), 15\% (B15) and 20\% (B20) $n$ - butanol at different loads and speeds. The cetane number of the blends is lower than basic fuel and is corrected to these of the neat diesel fuel. The differences in brake specific fuel consumption (BSFC) and exhaust emissions are compared with the baseline operations (when working with the neat diesel fuel). The cetane improver 2-EthylHexil Nitrate is used. Six types of fuels are investigated: B10 and B10 with cetane improver, B15 and B15 with cetane improver, B20 and B20 with cetane improver. This approach shows that the BSFC for fuel blends with corrected cetane number is closer to this with neat diesel fuel, especially at higher engine speeds. The exhaust smoke (D) for blends with corrected cetane number is lower than the neat diesel fuel and blends without cetane improver. There is no clear trend for NOx emission.

KEY WORDS: diesel fuel, n-butanol, fuel blends, cetane number, cetane improver, emission

(C) 2020 Published by University of Kragujevac, Faculty of Engineering

\footnotetext{
${ }^{I}$ Hristo Stanchev, PhD prof., University of Ruse, 8 Studentska St, 7017 Ruse, Bulgaria, hstanchev@uni-ruse.bg (*Corresponding author)

${ }^{2}$ Krasimir Markov, Assist. prof., University of Ruse, 8 Studentska St, 7017 Ruse, Bulgaria, krmarkov@uni-ruse.bg
} 


\section{ISTRAŽIVANJE DIZEL MOTORA KOJI RADI SA MEŠAVINOM DIZEL- BUTANOL GORIVA SA CETANSKIM POBOLJŠANJEM}

REZIME: Eksperimentalno istraživanje dizel motora se Common rail direktnim ubrizgavanjem je realizovano korišćenjem mešavine dizel goriva sa: 10\% (B10), 15\% (B15) i 20\% (B20) n-butanola pri različitim opterećenjima i brzinama. Cetanski broj mešavina je niži od baznog goriva i korigovan je na vrednosti za čisto dizel gorivo. Razlike u potrošnji goriva kočnice (BSFC) i emisije izduvnih gasova upoređene su sa osnovnim operacijama (kada se radi sa čistim dizel gorivom). Korišćen je 2-EthylHexil Nitrat za poboljšanje cetanskog broja. Ispitivano je 6 vrsta goriva: B10 i B10 sa cetanskim poboljšivaačem B15 i B15 sa cetanskim poboljšivačem, B20 i B20 sa cetanskim poboljšivačem. Ovaj pristup pokazuje da je BSFC za mešavine goriva sa korigovanim cetanskim brojem bliži onom sa čistim dizel gorivom, posebno na većim brzinama rada motora. Izduvni dim (D) za mešavine sa korigovanim cetanskim brojem je manji nego kod čistog dizel goriva i mešavina se bez cetanskog poboljšanja. Ne postoji jasan trend emisije NOx.

KLJUČNE REČI: dizel motor, n-butanol, mešavine goriva, cetanski broj, cetanski poboljšivače, emisija 


\title{
INVESTIGATION OF DIESEL ENGINE OPERATED WITH DIESEL FUEL-BUTANOL BLENDS AND CETANE IMPROVER
}

\author{
Hristo Stanchev, Krasimir Markov
}

\section{INTRODUCTION}

The high emission standards for greenhouse gases exist using of different type of high alcohols as an alternative fuels (blends with standard fuel). The new low cost technology for butanol production and its very close characteristics to fossil fuels lead to active scientific work all around the world for replacement of part of these fuels with butanol. There are lot hurdles to be overtaken to use high percentage of butanol in blends with diesel fuel. Butanol has lower cetane number which resulted in different type of combustion process. The main advantage of butanol as a fuel for internal combustion engines are higher flash point (safer for distribution and storage), less corrosive influence on fuel system, less evaporative emission, lower emission of smoke, $\mathrm{CO}$ and $\mathrm{HC}$ due to high oxygen content and higher laminar flame speed resulted in enhance reactions. There is no clear tendency in NOx emission changes because of concurrent between lower temperature and higher oxygen content, but NOx emission can be effectively reduced due to high EGR rate without increasing in smoke emission [1, 3, 5, 6]. Using butanol as a fuel for diesel engines leads to extended ignition delay period and this increases heat release quantity. As a result the specific effective fuel consumption increases with higher percentage of butanol. The temperature of exhaust gases is lower and effective efficiency is higher [2, 4].

\section{EXPERIMENTAL RESULTS}

\subsection{Test rig description}

An engine Fiat 1.9 JTD has been tested in laboratory condition on DC dynamometer. The fuel consumption is determined by mas flow method. For evaluation of emission components a 5-components gas analyser Auto Logic is used. For more precise NOx concentration measurement special analyser ECM NOx $5210(\mathrm{~g})$ is used. The exhaust smoke is measured by OPA-101 Nextech diesel smoke opacity meter. The technical specifications of equipment are given in next tables.

Table 1. Auto Logic 5-components gas analyzer

\begin{tabular}{|c|c|c|}
\hline Component & Range & Accuracy (rezolution) \\
\hline $\mathrm{HC}$ & $0-2000 \mathrm{ppm}$ & $1 \mathrm{ppm}$ \\
\hline $\mathrm{CO}$ & $0-15 \%$ & $0.001 \mathrm{vol} \%$ \\
\hline $\mathrm{CO} 2$ & $0-20 \%$ & $0.01 \mathrm{vol} \%$ \\
\hline $\mathrm{O} 2$ & $0-25 \%$ & $0.01 \mathrm{vol} \%$ \\
\hline NOx & $0-5000 \mathrm{ppm}$ & $1 \mathrm{ppm}$ \\
\hline A/F ratio & $0-72$ & 0.01 \\
\hline
\end{tabular}


Table 2. ECM NOx 5210(g) analyzer

\begin{tabular}{|c|c|}
\hline Component & Range \\
\hline NOx & $0-8000 \mathrm{ppm}$ \\
\hline$\lambda$ & $0.4-25$ \\
\hline $\mathrm{AFR}$ & $6.0-364$ \\
\hline$\Phi$ & $0.04-2.5$ \\
\hline $\mathrm{O}_{2}$ & $0.0-25 \mathrm{Vol} \%$ \\
\hline FAR x 10000 & $27-1667$ \\
\hline
\end{tabular}

The data from ECM gas analyzer are compensated depend on the pressure in place of NOx /O2 sensor

Table 3. OPA - 101 smoke opacity meter

\begin{tabular}{|c|c|}
\hline Parameter & Range (accuracy) \\
\hline Opacity & $0,0-100 \%(0,01 \%)$ \\
\hline Absorbtion coefficient $\mathrm{K}$ & $0,00-21,42 \mathrm{~m}-1(0,01 \mathrm{~m}-1)$ \\
\hline Engine oil temperature & $0-120{ }^{\circ} \mathrm{C}$ \\
\hline Engine speed & $0-5000 \mathrm{~min}^{-1}$ \\
\hline
\end{tabular}

Experimental study has been carried out to investigate the impact of the different butanoldiesel blends on the engine performance and emission levels under a variety of operating conditions (load and speed). The cetane number of fuel mixture is corrected to these of neat diesel fuel -51 points. For evaluation of influence of the lower cetane number of butanoldiesel blends on engine performance were conducted experiments with different fuel blends without cetane number corrections first. In references there is not exact cetane number of nbutanol. The data are as between 17 and 26 points. The cetane number of the butanol has been assumed 25 points in our case. This cetane number is used for calculation of quantity of cetane improver to be added to different fuel blends. Cetane improver 2-EthylHexil Nitrate, produced by "Very One" company is used. According to the technical specification of this product $100 \mathrm{ppm}$ volume concentration increases cetane number with 0,28 points or $400 \mathrm{ppm}$ approximately for 1 point increasing. Taking this into account, for the three fuel blend with 10, 15 and $20 \%$ butanol, the quantity of cetane improver for a liter fuel is given in Table 4.

Table 4. Quantity of cetane improver for reaching of fuel blends cetane number 51 points

\begin{tabular}{|c|c|c|c|}
\hline$\%$ butanol & $\begin{array}{c}\text { Cetane number }(\mathrm{CN}) \\
\text { of the blend }\end{array}$ & $\begin{array}{c}\text { Difference to 51 } \\
\text { points }\end{array}$ & $\begin{array}{c}\text { Quantity } \\
\text { 2-Ethylhexil Nitrate, } \\
\text { ml }\end{array}$ \\
\hline 10 & 48.4 & 2.6 & 1.04 \\
\hline 15 & 47.1 & 3.9 & 1.56 \\
\hline 20 & 45.8 & 5.2 & 2.08 \\
\hline
\end{tabular}

The results from investigation are shown in graphical form. For comparison at every figure for certain concentration of butanol are shown the results, obtained for neat diesel fuel, the diesel-butanol blend and the diesel-butanol-cetane improver blend.

\subsection{Analysis of the results}

At engine speeds $1500 \mathrm{~min}^{-1}$ and $2000 \mathrm{~min}^{-1}$ cetane number of fuel does not have significant influence on the combustion process and consequently on the power and brake specific fuel 
consumption (BSFC) for all types of blends. It is observed increase in NOx emissions and decrease in smoke emissions. At engine speed $2500 \mathrm{~min}^{-1}$ (Figure $1-3$ ) the correction of fuel blends cetane number has visible effect on the BSFC in comparison with the operation of the engine with fuel blends without cetane number correction. It is visible from the results that the BSFC does not differ from the engine operation with neat diesel fuel.

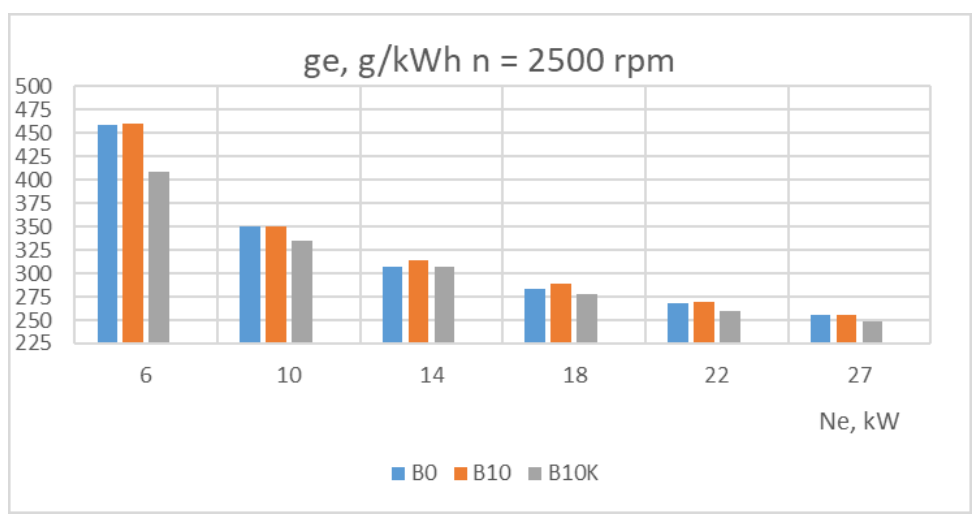

Figure 1. Change of BSFC (ge) at neat diesel fuel (B0), addition of 10\% butanol (B10) and B10 with cetane improver (B10K)

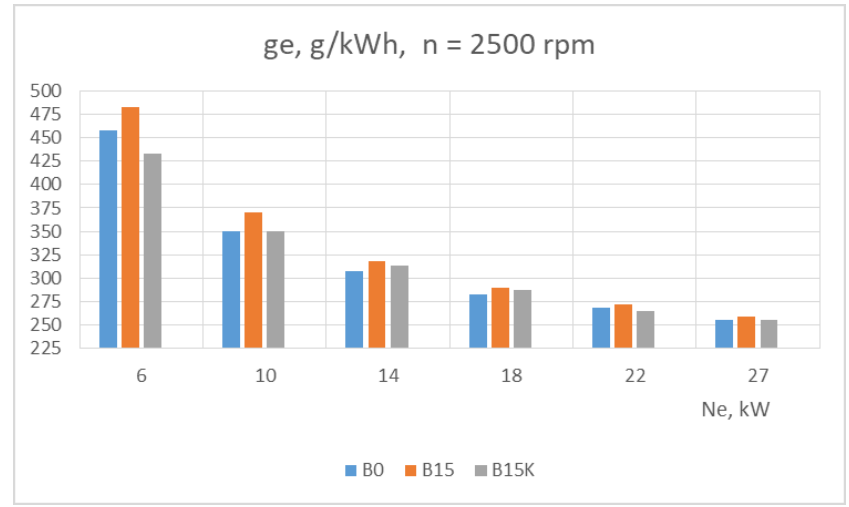

Figure 2. Change of BSFC at neat diesel fuel (B0), addition of $15 \%$ butanol (B15) and B15 with cetane improver (B15K)

From the obtained result it can be concluded that with addition up to $20 \%$ butanol to diesel fuel is possible to keep engine performance the same as with neat diesel fuel, without any modifications in exist injection program. Any modification requires reprogramming of electronic control unit on the base of experimental defined optimal injection program (pilot injection quantity and timing, main injection timing and late injection timing) at operation with dieselbutanol blends.

As is mentioned above, addition of butanol to diesel fuel has contradiction influence over the NOx emissions. Lower cetane number of diesel-butanol blends leads to extended ignition delay and increased in-cylinder temperature and accordingly higher NOx emissions. Higher content of oxygen in butanol has the same influence. Conversely, higher boiling point of butanol reduces the flame temperature in the combustion chamber, which leads to 
decrease in NOx emission. This effect is more crearly visible at low engine loads when the heat for evaporation exceeds the combustion temperature. Also, the presence of 2-ethylhexyl nitrate cetane improver introduces a new fuel-borne NOx formation mechanism to the combustion process, which increases NOx emissions. The increase in NOx emission is formed by the decomposition of the cetan improver. Reduction of smoke emissions, when using diesel-butanol blends, is due to increased content of oxygen in fuel blends.

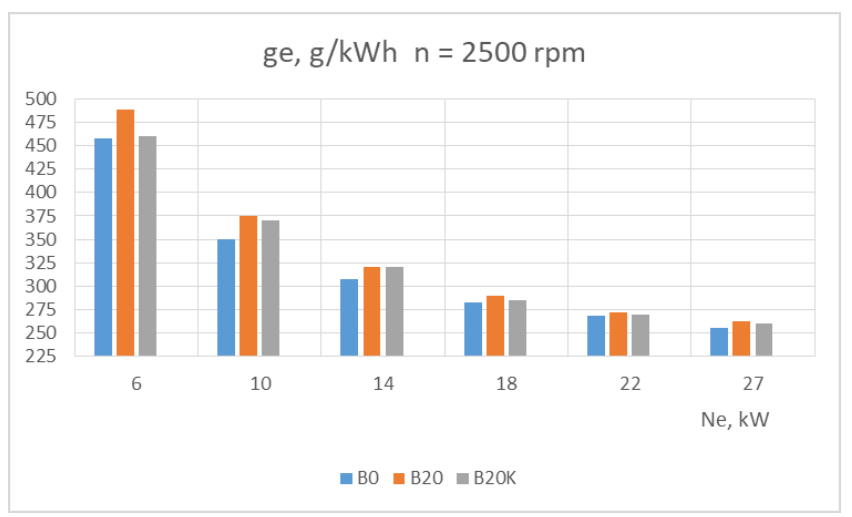

Figure 3. Change of BSFC at neat diesel fuel (B0), addition of $20 \%$ butanol (B20) and B20 with cetane improver (B20K)

Results for smoke (D) emissions at all investigated working regimes and fuel blends are shown in Figure 4 to Figure 12. There is not clear trend at different operation conditions. The main reason for this is different influence of ignition delay period at different engine speeds with correction of blend's cetane number. At higher loads, when cetane improver is added, the smoke emission is close to that without cetane improver. This effect reduces with increasing of butanol percentage in blends. For full estimation of the effect of fuel cetane number on the combustion process must be proceed in-cylinder pressure measurement (indicator diagram).

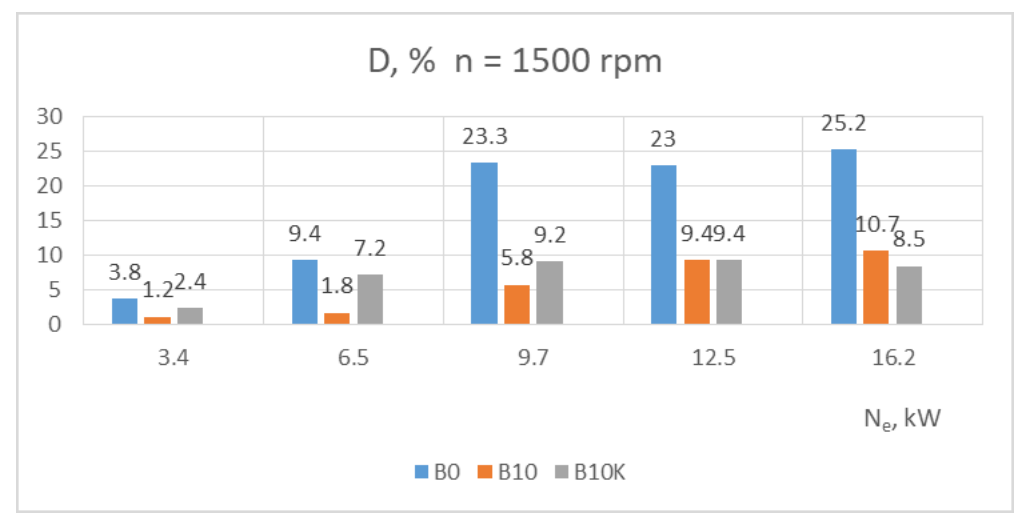

Figure 4. Change of smoke (D) at neat diesel fuel (B0), addition of $10 \%$ butanol (B10) and B10 with cetane improver (B10K) 
Investigation of diesel engine operated with diesel fuel-butanol blends

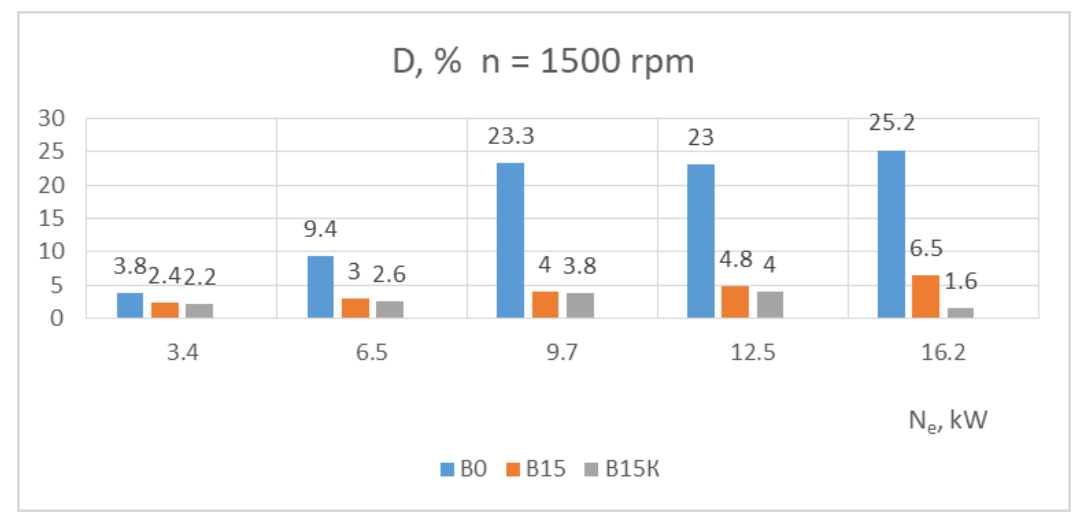

Figure 5. Change of smoke (D) at neat diesel fuel (B0), addition of 15\% butanol (B15) and B15 with cetane improver (B15K)

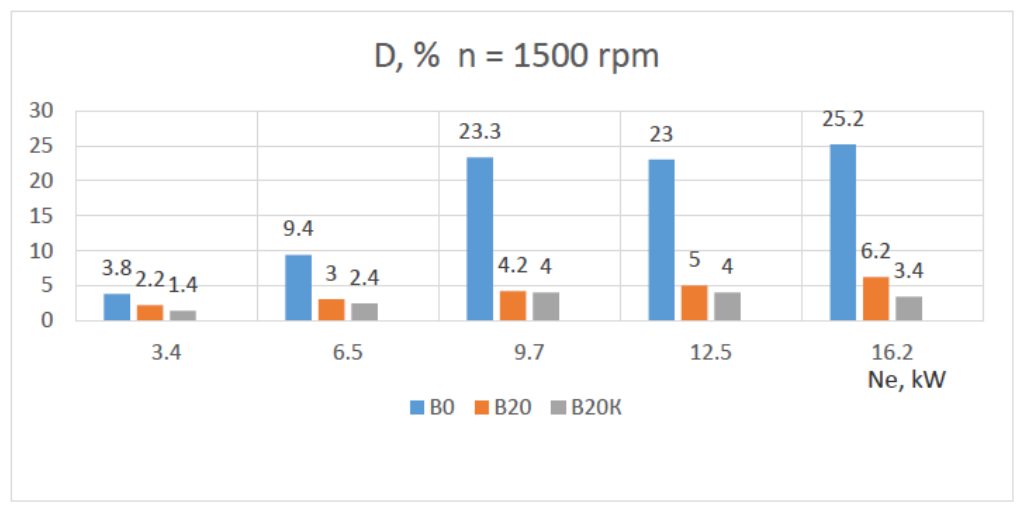

Figure 6. Change of smoke (D) at neat diesel fuel (B0), addition of $20 \%$ butanol (B20) and B20 with cetane improver (B20K)

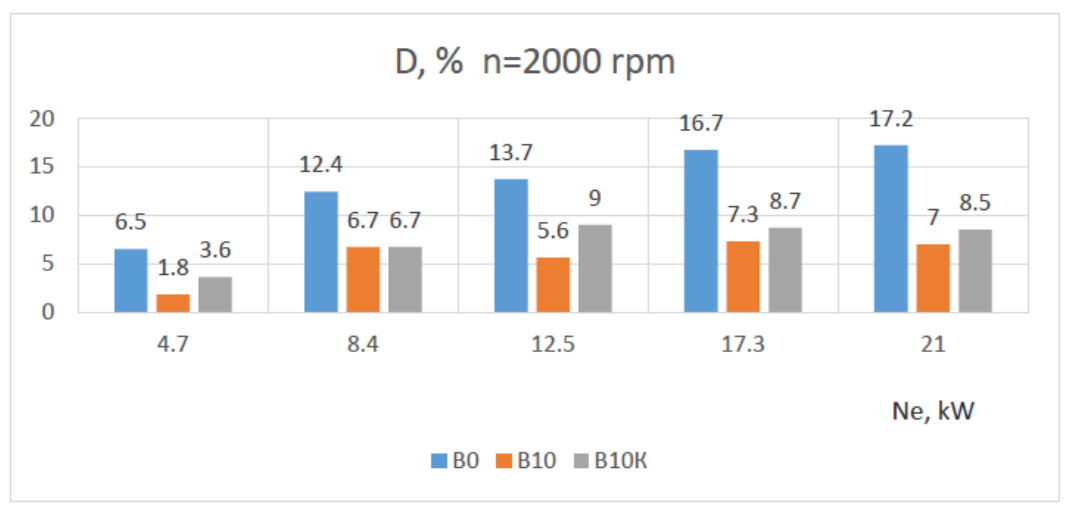

Figure 7. Change of smoke (D) at neat diesel fuel (B0), addition of $10 \%$ butanol (B10) and B10 with cetane improver (B10K) 


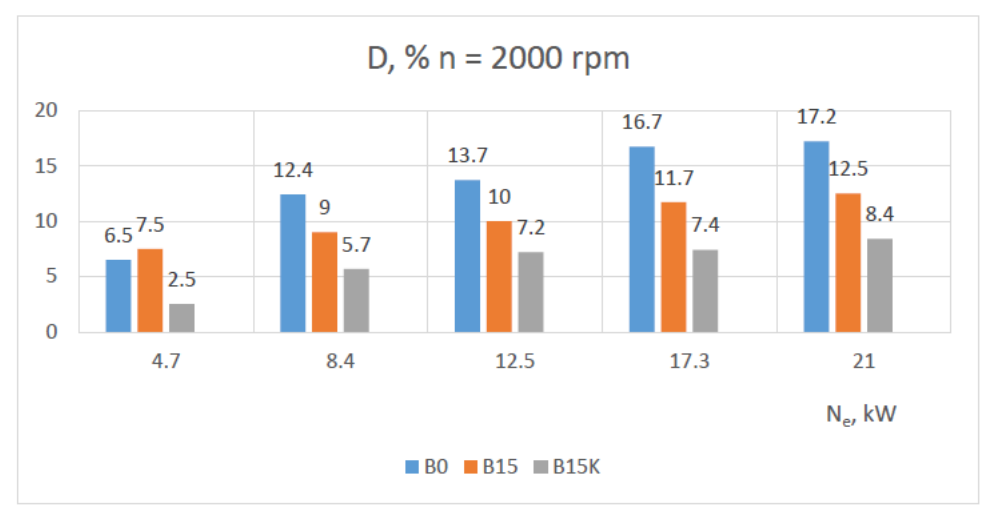

Figure 8. Change of smoke (D) at neat diesel fuel (B0), addition of $15 \%$ butanol (B15) and B15 with cetane improver (B15K)

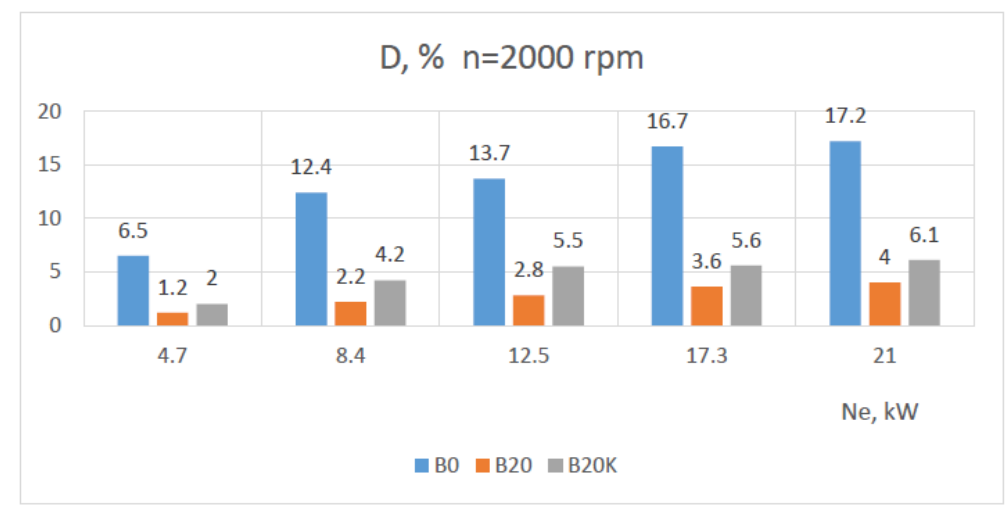

Figure 9. Change of smoke (D) at neat diesel fuel (B0), addition of $20 \%$ butanol (B20) and B20 with cetane improver (B20K)

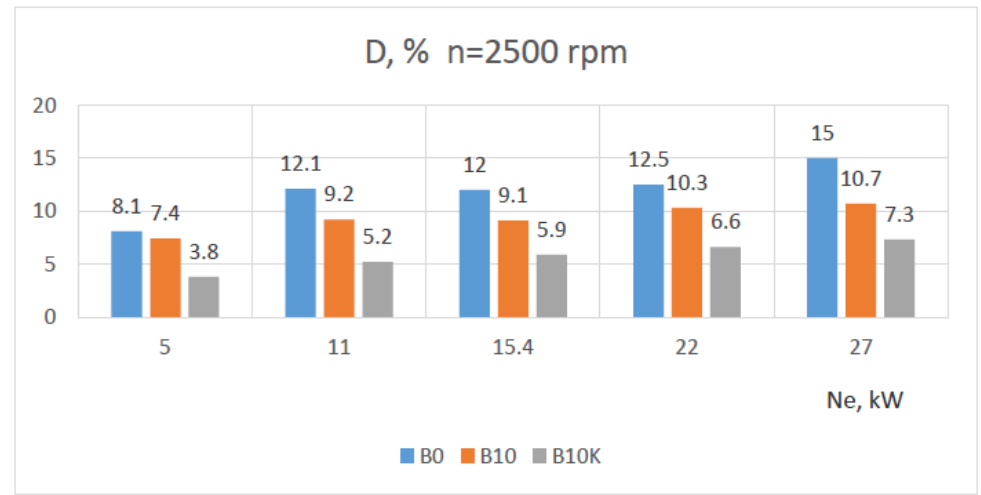

Figure 10. Change of smoke (D) at neat diesel fuel (B0), addition of $10 \%$ butanol (B10) and B10 with cetane improver (B10K) 
Investigation of diesel engine operated with diesel fuel-butanol blends and cetane improver

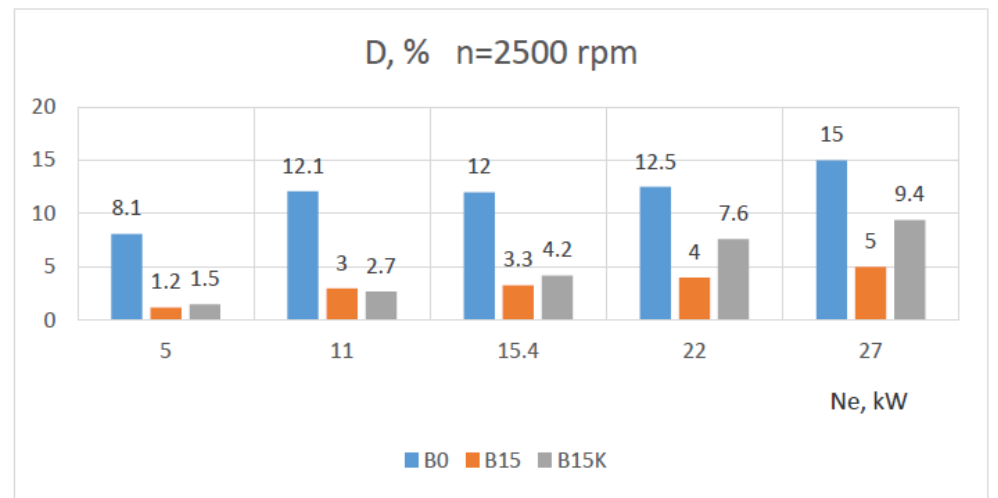

Figure 11. Change of smoke (D) at neat diesel fuel (B0), addition of $15 \%$ butanol (B15) and B15 with cetane improver (B15K)

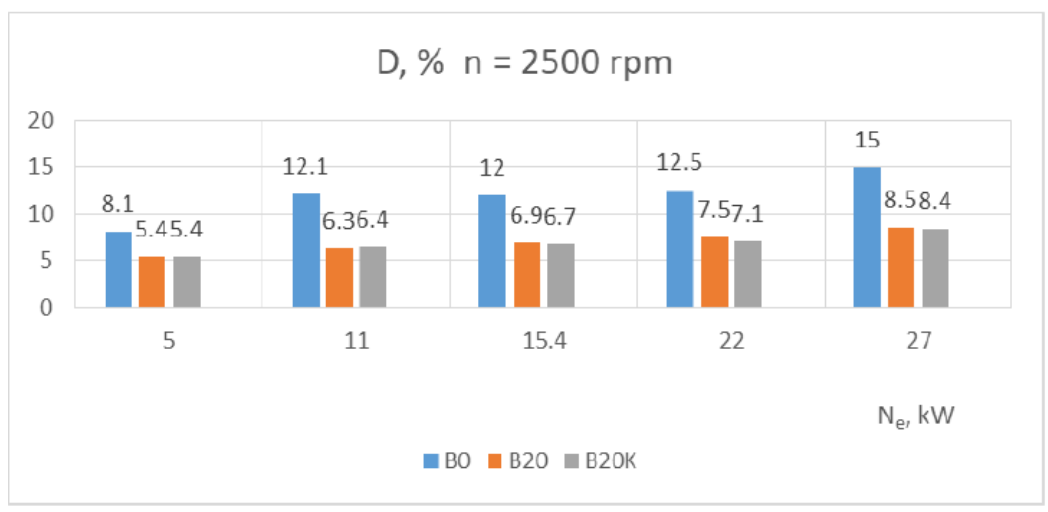

Figure 12. Change of smoke (D) at neat diesel fuel (B0), addition of $20 \%$ butanol (B20) and B20 with cetane improver (B20K)

As an example, results for NOx emissions at engine speed $\mathrm{n}=2500 \mathrm{~min}^{-1}$ and for all fuel blends are shown in Figure 13 to Figure 15. It is evident, that there is not clear trend in NOx concentration at different load conditions and fuel blends. 


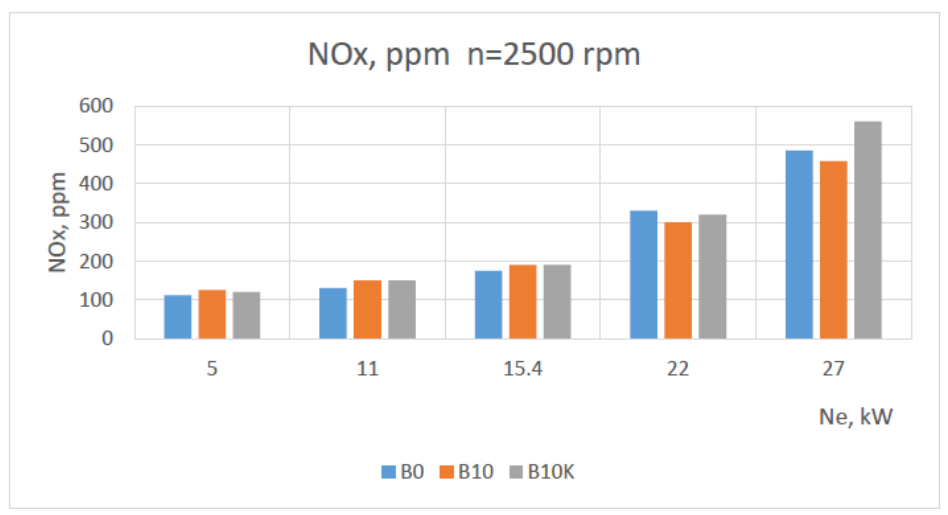

Figure 13. Change of NOx concentration at neat diesel fuel (B0), addition of $10 \%$ butanol (B10) and B10 with cetane improver (B10K)

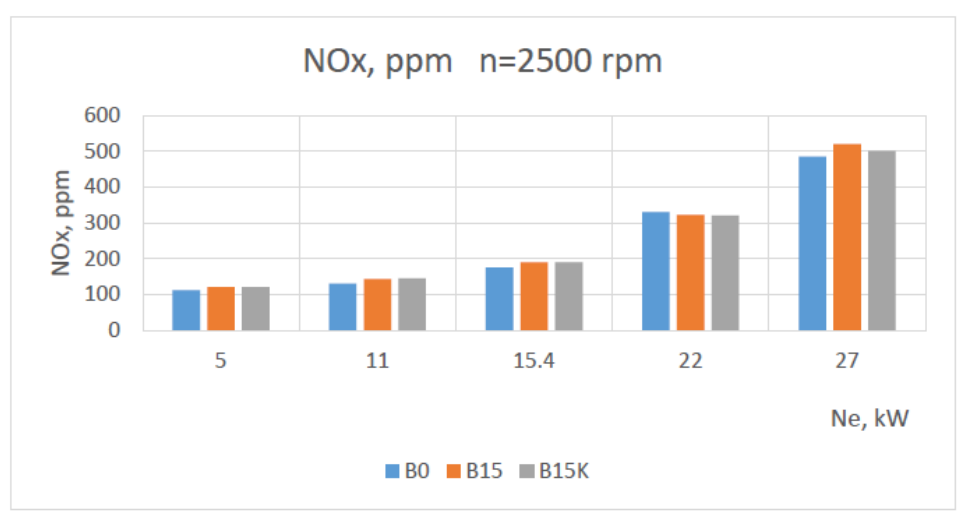

Figure 14. Change of NOx concentration at neat diesel fuel (B0), addition of $15 \%$ butanol (B15) and B15 with cetane improver (B15K)

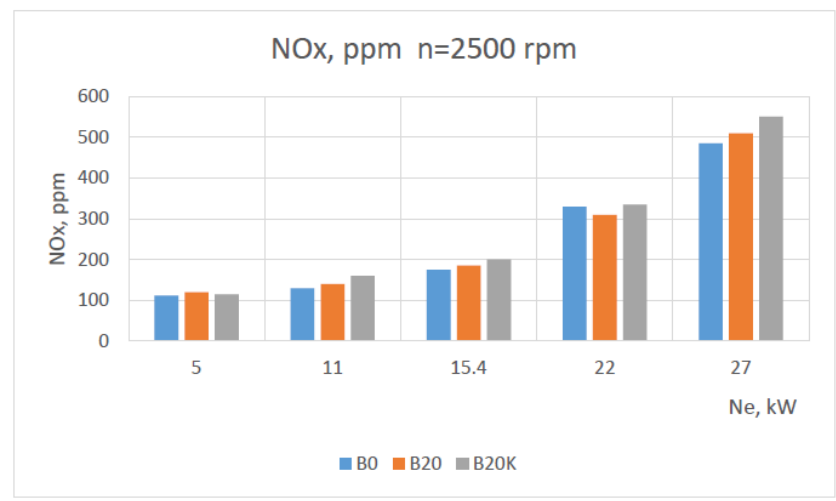

Figure 15. Change of NOx concentration at neat diesel fuel (B0), addition of $20 \%$ butanol (B20) and B20 with cetane improver (B20K) 


\section{CONCLUSIONS}

1. Brake specific fuel consumption, when engine work with addition of cetane improver is almost equal to this with neat diesel fuel. The effect is better at higher engine speed due to stronger influence of fuel cetane number on the combustion process at these speeds.

2. It is evident from experiment that fuel (fuel blends) cetane number has different influence on smoke emission at different engine speed. It is observed saving or slightly more or less smoke emissions, compare with engine operation without cetane improver.

3. There is no need of engine control unit reprogramming when up to $20 \%$ n-butanol is added to diesel fuel and fuel blends cetane number is corrected.

\section{REFERENCES}

[1] Algayyim, S., Wandel, A., Yusaf, T., Hamawand, I.: "The impact of n-butanol and iso-butanol as components of butanol-acetone (BA) mixture-diesel blend on spray, combustion characteristics, engine performance and emission in direct injection diesel engine", Energy, Vol. 140, Part 1, 2017, pp 1074-1086.

[2] Chen, Z., Liu, J., Han, Z., Du, B., Liu, Y., Lee, C.: "Study on performance and emissions of a passenger-car diesel engine fueled with butanol-diesel blends", Energy, Vol. 55, 2013, pp 638-646.

[3] Dobre, A., Pană, C., Nuţu, N., Cernat, Al.; Bondoc, I. D.: "Bio-butanol-alternative fuel for Diesel engine" INMATEH-Agricultural Engineering, Vol. 42, Issue 1, 2014, pp 145-152.

[4] Giakoumis, G., Rakopoulos, C., Dimaratos, A., Rakopoulos, D.: "Exhaust emissions with ethanol or n-butanol diesel fuel blends during transient operation", Renewable and Sustainable Energy Reviews, Vol. 17, 2013, pp 170-190.

[5] Karabektas, M., Hosoz, M.: "Performance and emission characteristics of a diesel engine using isobutanol-diesel fuel blends", Renewable Energy, Vol. 34, Issue 6, 2009, pp 1554-1559.

[6] Rajesh Kumar, B., Saravanan S., Rana D., Nagendran A.: "A comparative analysis on combustion and emissions of some next generation higher-alcohol/diesel blends in a direct-injection diesel engine", Energy Conversion and Management, Vol. 119, 2016, pp 246-256. 